\title{
Growth uncoupling and the relationship between shell growth and metabolism in the soft shell clam Mya arenaria
}

\author{
Daniel E. Lewis, Robert M. Cerrato* \\ Marine Sciences Research Center, State University of New York, Stony Brook, New York 11794-5000, USA
}

\begin{abstract}
The goal of this study was to investigate whether shell growth reflects metabolic rate rather than overall or somatic tissue production in the soft shell clam Mya arenaria. This was accomplished by conducting laboratory experiments exposing clams to different levels of food, immersion period and temperature in order to uncouple shell and soft tissue growth, and then determining if shell growth and oxygen consumption remained positively correlated. Soft shell clams were raised in a simulated intertidal system for 2 to $3 \mathrm{wk}$ to acclimate them to experimental conditions. After acclimation, oxygen consumption, a measure of metabolic activity, ingestion rate, a measure of energy intake, shell growth and soft tissue growth were estimated for all individuals. Tissue and shell growth were successfully uncoupled in all experiments. In the 2 experiments where significant changes in shell growth, soft tissue growth and oxygen consumption occurred, shell growth was positively correlated to oxygen consumption. Soft tissue growth was either uncorrelated or negatively correlated to oxygen consumption and shell growth. Shell transparency in thin sections increased with metabolic rate, while shell growth line clarity decreased in those treatments most stressful to the clams (i.e. low food level and high temperature). Our results are consistent with the hypothesis that shell growth is coupled to metabolic activity and is not a measure of somatic tissue production. We suggest that information on physiological rate processes is recorded in the shell of bivalves, and that growth line patterns may be used to reconstruct metabolic rates from field collected individuals.
\end{abstract}

KEY WORDS: Microgrowth Shell growth - Uncoupling $\cdot$ Metabolic rate Bivalve

\section{INTRODUCTION}

For bivalve mollusks, change in body weight and shell dimension have both been used to measure growth (e.g. Borrero \& Hilbish 1988). Change in soft tissue weight is generally considered the best index of growth (Hilbish 1986, Griffiths \& Griffiths 1987), since it is frequently interpreted as reflecting overall production. Tissue weight can only be accurately measured as dry weight in sacrificed animals. Initial weight must, therefore, be estimated in some way in order to calculate production. This is usually done by measuring shell length and using a weight-length regression derived from an independent sample.

Change in shell length (or some other shell dimension) has an obvious advantage over weight as an in-

\footnotetext{
- Addressee for correspondence

E-mail: rcerrato@notes.cc.sunysb.edu
}

dex of growth since multiple length measurements can be made on an individual by marking the edge of the shell and periodically remeasuring its size. Growth can also be reconstructed from microgrowth patterns preserved in the shell. Unlike weight-derived estimates, shell growth measurements do not depend on an allometric relationship obtained from other individuals to provide an estimate of initial size, and because it is more direct, shell length is the most commonly used indicator of growth (e.g. Griffiths \& Griffiths 1987). However, the linkage between shell growth and other physiological rate functions (especially production) is not readily established. Shell is, after all, an extracellular structure, and it is predominantly composed of inorganic material.

Soft tissue weight changes and shell changes are often assumed to be equivalent measures of growth (Borrero \& Hilbish 1988, Grizzle \& Morin 1989, Nakaoka \& Matsui 1994), at least in a time averaged sense. 
Justification for this assumption is the common observation that samples show a direct relationship between tissue weight and shell size. However, in studies where both tissue weight and shell size changes have been measured simultaneously, a number of investigators have convincingly demonstrated that these measures vary independently and often become uncoupled in time even in non-reproductive individuals (Ceccherelli \& Barboni 1983, Frechette \& Bourget 1985, Hilbish 1986, Peterson \& Fegley 1986, Borrero \& Hilbish 1988, Hawkins et al. 1989, Harvey \& Vincent 1990). For example, Borrero \& Hilbish (1988) measured tissue and shell growth over a complete growing season in a South Carolina (USA) population of the ribbed mussel Geukensia demissa. They found that rates of tissue and shell growth varied independently and shell growth remained positive, even in periods when tissue growth was negative. In view of the uncoupling between tissue growth and shell growth, and accepting the reasonable assumption that tissue weight change is the best index of production, what physiological process does change in shell size reflect?

Uncoupling between the growth of somatic tissue and otoliths, another calcified, extracellular structure. has been observed frequently in fish (e.g. Mosegaard et al. 1988, Reznick et al. 1989, Secor \& Dean 1989, Hovenkamp 1990, Umezawa \& Tsukamoto 1991, Wright et al. 1991, Francis et al. 1993, Hoff \& Fuiman 1993). Mosegaard et al. (1988) found considerable evidence for growth uncoupling in Arctic char raised at different temperatures. In their laboratory experiment, somatic growth rate reached an optimum at an intermediate temperature and declined at the highest temperatures. In contrast, otolith growth rate continued to increase with increased temperature. Mosegaard et al. (1988) explained the decline in somatic growth rate in energetic terms, with respiration progressively utilizing a larger fraction of assimilated energy at higher temperatures. These authors then proposed that otolith growth is related to some 'metabolic expression of the fish' that continued to increase with temperature. Unfortunately, no metabolic measurements were available to test this hypothesis.

In light of these observations, the goal of this study was to test whether variations in bivalve shell growth, and more specifically the size and structure of microgrowth patterns, reflect changes in metabolic rate rather than overall or somatic tissue production (i.e. non-reproductive and non-shell related production). Our approach was to conduct laboratory experiments that produced uncoupled tissue and shell growth conditions in the soft shell clam Mya arenaria, and then determine if shell growth and oxygen consumption (as a measure of metabolism) remained positively correlated.

\section{MATERIALS AND METHODS}

General design. Soft shell clams Mya arenaria were collected as needed between September 1993 and December 1994 from an intertidal location in Mt. Sinai Harbor, an embayment of Long Island Sound, NY, USA. For all experiments, clams measuring between 60 and $70 \mathrm{~mm}$ in length, and carefully matched to be of similar size and total body weight, were brought to the Flax Pond Marine Laboratory in Old Field, NY. Individual clams were placed in butyrate tubes $(10.2 \mathrm{~cm}$ in diameter and $23 \mathrm{~cm}$ in length) containing clean, azoic sand (Fig. 1). A $1 \mathrm{~mm}$ mesh screen was epoxied $2.5 \mathrm{~cm}$ from the bottom of the tube to hold the sand in place

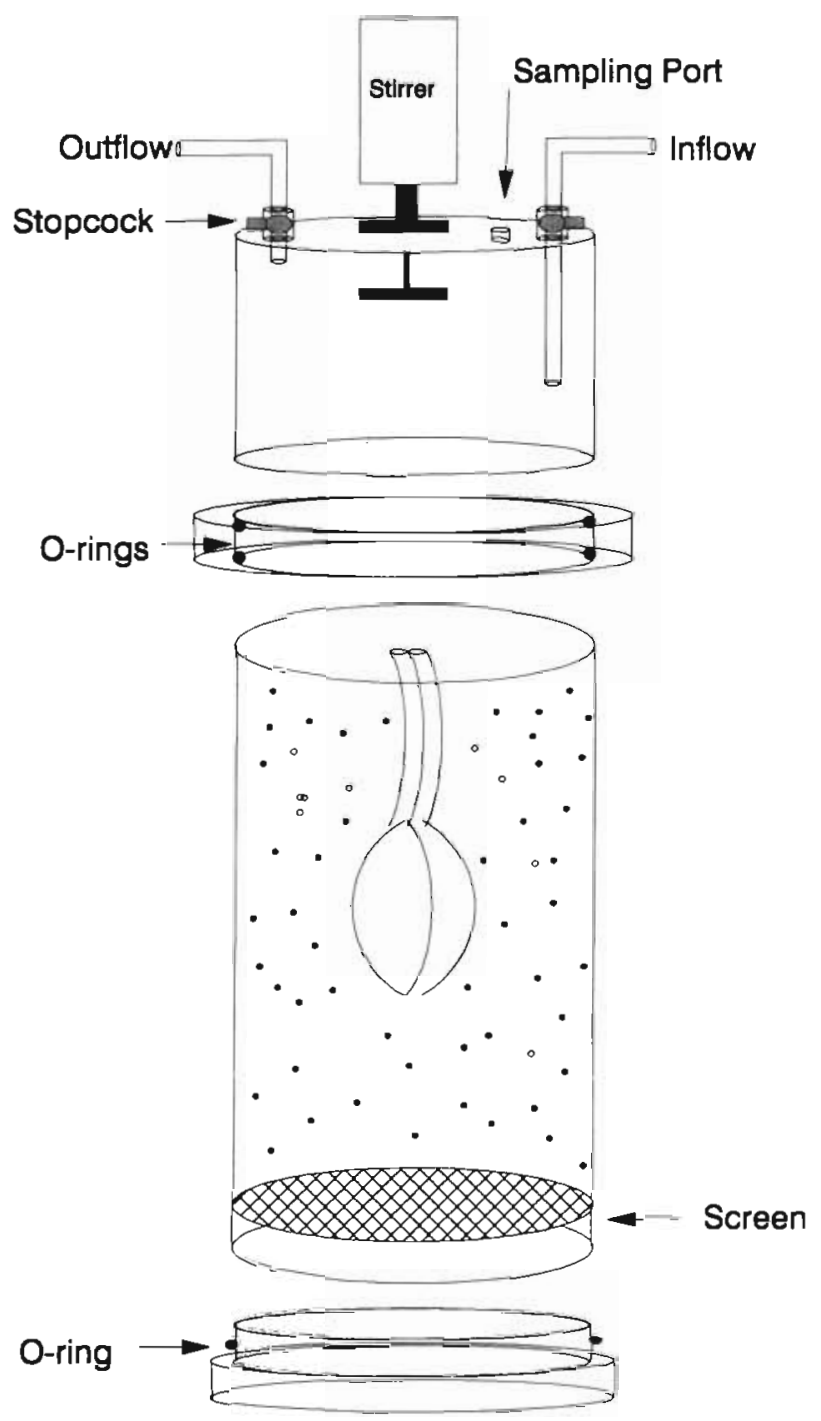

Fig. 1. Diagram of the measurement apparatus in exploded view. Measurement apparatus consisted of measurement chamber top, connecting ring, tube containing experimental clam in sand, and bottom 
and to allow seawater to freely drain or percolate up through the sand depending on the water level outside the tube. Clams could easily move both laterally and vertically in the tube and adjusted to their preferred burial depth in less than $1 \mathrm{~d}$. Tubes with clams and control tubes containing only sand were held under immersed conditions for $24 \mathrm{~h}$ and then transferred to the experimental system.

Experiments were conducted in a mock tidal system to simulate natural intertidal conditions. The system produced periods of low and high tide by using submersible pumps and electric timers and consisted of 4 buckets and reservoir tanks, 1 for each treatment Treatment buckets were covered, 19 l, high density polyethylene pails. They contained 3 tubes, 2 tubes with a single clam in each and a control tube, that were supported $2 \mathrm{~cm}$ off the bottom of the bucket to permit free water exchange through their screened bottoms An inflow port from the reservoir was located at the bottom of the treatment bucket. Water upwelled in the treatment bucket and overflowed through a standpipe back to the reservoir tank. The reservoir tanks were 64 l, high density polyethylene tanks with covers to prevent evaporation. Water was pumped at about $1 \mathrm{l}$ min $^{-1}$ from the reservoir tanks to treatment buckets During immersion or high tide periods, seawater continuously recirculated between treatment buckets and reservoirs. Emersion or low tide periods were created when the timers shut the pumps off and water drained from the buckets by flowing back through the pumps to the reservoir tanks located below the buckets. Tidal cycles were exactly $12 \mathrm{~h}$ long to facilitate a regular maintenance schedule.

Water in the reservoir tanks was changed daily during a low tide period to keep food levels as constant as possible and to remove metabolic products. Replacement water was filtered through a series of $30 \mu \mathrm{m}$ $1 \mu \mathrm{m}$ and $0.5 \mu \mathrm{m}$ cartridge filters. Particles less than $1 \mu \mathrm{m}$ are below the lower limit of Mya arenaria's filtering ability (Wright et al. 1982). The centric diatom Thalassiosira weissflogii was then added as food. Each reservoir tank was aerated to keep algae in suspension. Algae at 20 times the concentration in the reservoir tanks were continuously delivered to the reservoir tanks by peristaltic pump to replace food filtered by the clams. Using preliminary experiments and testing several options with a simple food delivery/feeding model, the experimental system was capable of maintaining food concentrations within $\pm 40 \%$ of the nominal value after 2 tidal cycles, as long as the clam's filtration rates ranged between 50 and $200 \%$ of their estimated levels (Lewis 1996).

All experiments were run in a completely randomized block design consisting of 4 treatment levels per replicate. Each replicate ran for approximately 2 to
$3 \mathrm{wk}$ to allow the clams to acclimate to experimental conditions. After the acclimation period, chamber tops and bottoms were attached to the animal and control tubes, and ingestion rate and oxygen consumption were measured. All experiments consisted of 5 replicates.

Experimental treatments. (1) Food experiment: Treatment levels for this experiment were set at 12.5 , 25,50 , and $100 \%$ of an algal concentration expected to be optimal for growth. The full food level was taken to be 2400 Thalassiosira weissflogii cells $\mathrm{ml}^{-1}$ We expected that the full food level would support growth since it is equivalent to $400 \mu \mathrm{g}$ organic carbon $\mathrm{l}^{-1}$ and falls within the range ( 300 to $700 \mu$ g organic carbon $\mathrm{l}^{-1}$ ) considered to be best for clam culture (Malouf \& Bricelj 1989). Temperature was held at $15 \pm 1^{\circ} \mathrm{C}$, and the immersion period was $8 \mathrm{~h}$ per tidal cycle.

Increased feeding and associated absorption and digestion costs have been shown to cause an increase in oxygen consumption of bivalves (Bayne \& Newell 1983). Therefore, shell growth was predicted to increase with food level in this experiment as clams become more active at higher food levels. Shell growth was also expected to continue at the lowest algal concentrations, but tissue weight would decline because clams would not receive a sufficient food ration.

(2) Immersion experiment: Treatment levels were 6 , 8,10 , and $11.25 \mathrm{~h}$ of immersion per tidal cycle. Temperature was held at $15 \pm 1^{\circ} \mathrm{C}$. Food concentration was adjusted to 4800 cells $\mathrm{ml}^{-1}$ to insure that food was not limiting.

Increased immersion time was expected to result in increased shell growth as the total period available for aerobic metabolism increased. Shell growth would increase linearly with immersion time if Mya arenaria showed no adjustment in respiration rate to compensate for differences in immersion period. We also expected that the line separating microgrowth increments would be most sharply defined during the longest emersion times, since low tide corresponds to the period when the line separating growth increments forms (Richardson et al. 1981).

(3) Temperature experiment: Treatment levels for the temperature experiment were $5,12,20$, and $27^{\circ} \mathrm{C}$. To maintain constant temperatures, reservoir tanks were placed in 4 separate temperature control baths At the beginning of each experimental run, temperatures were gradually changed from ambient over a $2 \mathrm{~d}$ period to allow the clams a chance to adjust to the treatment conditions. Immersion period was $8 \mathrm{~h}$ per tidal cycle. Food concentration in the reservoir tanks was adjusted to 4800 cells $\mathrm{ml}^{-1}$ to insure that food was not limiting.

Kennedy \& Mihursky (1972) have shown that the acclimated oxygen consumption rate of Mya arenaria 
increased monotonically over the temperature treatment range of this experiment. Furthermore, the $Q_{10}$ for clearance rate was found to be $\sim 1$ in $M$. arenaria for temperatures between 5 and $20^{\circ} \mathrm{C}$ (Lowe \& Trueman 1972). Assuming no difference in energy intake with treatment, tissue weight change would vary inversely with temperature and could be positive at the lowest and negative at the highest treatment temperature(s). We expected that shell growth would, like oxygen consumption but unlike tissue weight change, increase with temperature.

Design of the measurement chamber. To minimize disturbance, the measurement chamber apparatus used to estimate ingestion rate and oxygen consumption was designed to connect directly to the tubes that housed the clams (Fig. 1). The measurement chamber top was made from Lexan tubing and had 2 ports for flow, a sampling port, and an attached magnetic stirrer. Water was mixed by a magnet suspended in the chamber. A motor with a second magnet on its shaft was connected to a post on the outside of the chamber. A speed controller attached to the motor was set to produce a stirring rate of about $60 \mathrm{rpm}$. The rate was adjusted to thoroughly mix the water in the chamber without resuspending sand. The overall volume of the measurement chamber top was about $660 \mathrm{ml}$.

The chamber top was attached to the tube by constructing a large, Lexan ring that fits around the bottom of the chamber and the top of the tube containing the clam. An O-ring on the inner surface of this ring created the seal between the ring and the tube. The measurement chamber then slid into the upper half of the ring and a second $O$-ring was used to create a seal.

The bottom of the measurement chamber apparatus was a Lexan disk that attached to the bottom of the tube. This bottom disk was plug shaped and an O-ring prevented water from draining out of the bottom and made the entire chamber top-tube assembly water and airtight. This system allowed the clam to be virtually undisturbed and remain in sediments in a natural upright position during oxygen consumption and ingestion rate measurements.

Ingestion rate and oxygen consumption. To measure ingestion rate and oxygen consumption, tubes containing clams and control tubes were gently removed from the treatment buckets near the end of an emersion period. They were transferred to the reservoir tanks and slowly submerged. Measurement chamber tops and bottoms were attached under water to exclude air bubbles. Inflow and outflow lines were connected to ports on the chamber tops, and flow rates were adjusted and calibrated for each individual chamber to about $40 \mathrm{ml} \mathrm{min}^{-1}$, a rate that allowed steady state chlorophyll a ( $\mathrm{chl}$ a) concentrations to remain above $75 \%$ of inflow conditions. Flow to all chambers was maintained for at least $1 \mathrm{~h}$ beyond the time the siphon of the last clam in any run surfaced and the clam was observed to be pumping.

At the end of the waiting period, water samples for the ingestion rate measurement and initial oxygen concentration measurement were collected. Samples for ingestion rate were taken by collecting outflow water for $5 \mathrm{~min}$. Samples for oxygen concentration were extracted through the sampling ports using a $10 \mathrm{ml}$ syringe. With the outflow ports closed and inflow continuing, these samples were taken without allowing air bubbles to form in the chamber. The inflow and sampling ports were then closed to initiate an incubation period. Oxygen uptake incubations lasted from 15 to 90 min depending on water temperature. Incubation time was adjusted to obtain an easily measurable concentration difference while keeping the final oxygen concentration above $75 \%$ of the initial level. Pedersen (1992) showed that Mya arenaria altered its oxygen uptake behavior only when oxygen levels fell below $25 \%$ saturation, a level never reached in the present study. At the end of the incubation time, the final $10 \mathrm{ml}$ water sample for the oxygen consumption measurement was taken.

Water samples collected for ingestion rate measurement were filtered through $47 \mathrm{~mm}$ Whatman GF/C glass fiber filters and then stored at $-20^{\circ} \mathrm{C}$. Chl a was determined by in vitro fluorometry (Parsons et al. 1984) using a Turner Designs Model 10 Fluorometer. Feeding rate $(F R)$ was estimated from the removal of chl $a$ in the flow-through measurement chamber as $F R=F\left(C_{c}\right.$ $C_{a}$ ) where $F$ is the flow rate, and $C_{c}$ and $C_{a}$ are the outflow chl a concentrations in the water of the control and clam chambers, respectively. Ingestion rate was then estimated from the product of feeding rate and immersion period. Concentrations of algae were below the threshold of pseudofeces production in all experiments.

Oxygen concentrations were measured by a microwinkler technique modified from the method in Carpenter (1965) and developed by R. A. Aller (pers. comm.). Respiration rate was determined from the routine rate of oxygen consumption (Bayne \& Newell 1983) and was calculated as the difierence between initial and final oxygen concentrations, corrected for any consumption in the control chamber, divided by the incubation time. Oxygen consumption over the tidal cycle was then calculated from the product of respiration rate and immersion period.

Respiration is a reasonable measure of metabolism in Mya arenaria. Like most bivalves (de Zwann \& Wijsman 1976), $M$. arenaria utilizes both aerobic and anaerobic metabolic pathways, but the aerobic pathway is dominant when respiration is time averaged over the tidal cycle. Pedersen (1992) measured a 12-fold difference in heat production between periods of activity and 
inactivity in soft shell clams. This is probably an underestimate of the typical difference between aerobic and anaerobic metabolism, since Pedersen kept the clams unfed for $5 \mathrm{~d}$ prior to measurement, and bivalves respond to starvation by reducing respiration to conserve energy (Bayne \& Newell 1983). Energy consumed by the anaerobic pathway in bivalves has been estimated to be only $5 \%$ of the total heat loss during an entire tidal cycle (Famme et al. 1981, Shick et al. 1983).

Tissue growth. Tissue growth rate was measured by estimating the average tidal cycle change in ash-free dry weight (AFDW). Initial weights were estimated from AFDW versus shell length regressions calculated from independent samples of clams collected at the same time as the experimental run. AFDW and shell length data in these samples were fit by nonlinear least squares to the allometric equation $W=a L^{b}$, where $W$ is $A F D W, L$ is shell length, and $a$ and $b$ are fitted parameters.

Shell growth. Thin sections of the chondrophore of all experimental clams were prepared for microgrowth increment analysis using methods outlined in Cerrato et al. (1991). Shell growth in the chondrophore was measured with an optical micrometer under $400 \times$ magnification. Shell produced during an experimental run was visible as a band of increments at the edge of the chondrophore. This new shell was generally clearly marked by a change in shell opacity, an especially distinct growth increment, and/or a change in semidiurnal increment thickness.

In addition to microgrowth increment measurements, qualitative changes in shell transparency and increment clarity were made to determine if these features varied with metabolic rate. Shell growth during the experimental period was classified as translucent or opaque by comparing it to seasonal patterns in the rest of the shell. Translucent shell typically forms in summer and opaque shell is produced in fall through winter (Cerrato et al. 1991). Growth increments during the experimental period were classified as distinct if more than half of the expected number of semidiurnal increments were easily identified. Whether increments are distinct or not depends in part on the clarity of the lines between increments. These lines are formed during emersion periods (Richardson et al, 1981).

Data analysis. The principal method of analysis in this study was to perform a simple linear correlation between dependent variables. Oxygen consumption, ingestion rate, tissue growth and shell growth rates for the 2 clams in each treatment bucket were averaged prior to any statistical analysis. A significant outcome in a randomized block analysis of variance or a significant linear regression trend were used as criteria to identify those variables that actually responded to the experimental treatments. Correlations were attempted only for those variables that met the criteria.

\section{RESULTS}

\section{Food experiment}

Ingestion rate was the only variable that exhibited a significant treatment effect in the food experiment. Ingestion rate was 9 times greater at the 2 highest food levels when compared to the 2 lowest food levels $(F=$ 3.67 , df $=3,12, p<0.05$; Fig. 2). Oxygen consumption, shell growth, and soft tissue growth varied consider-

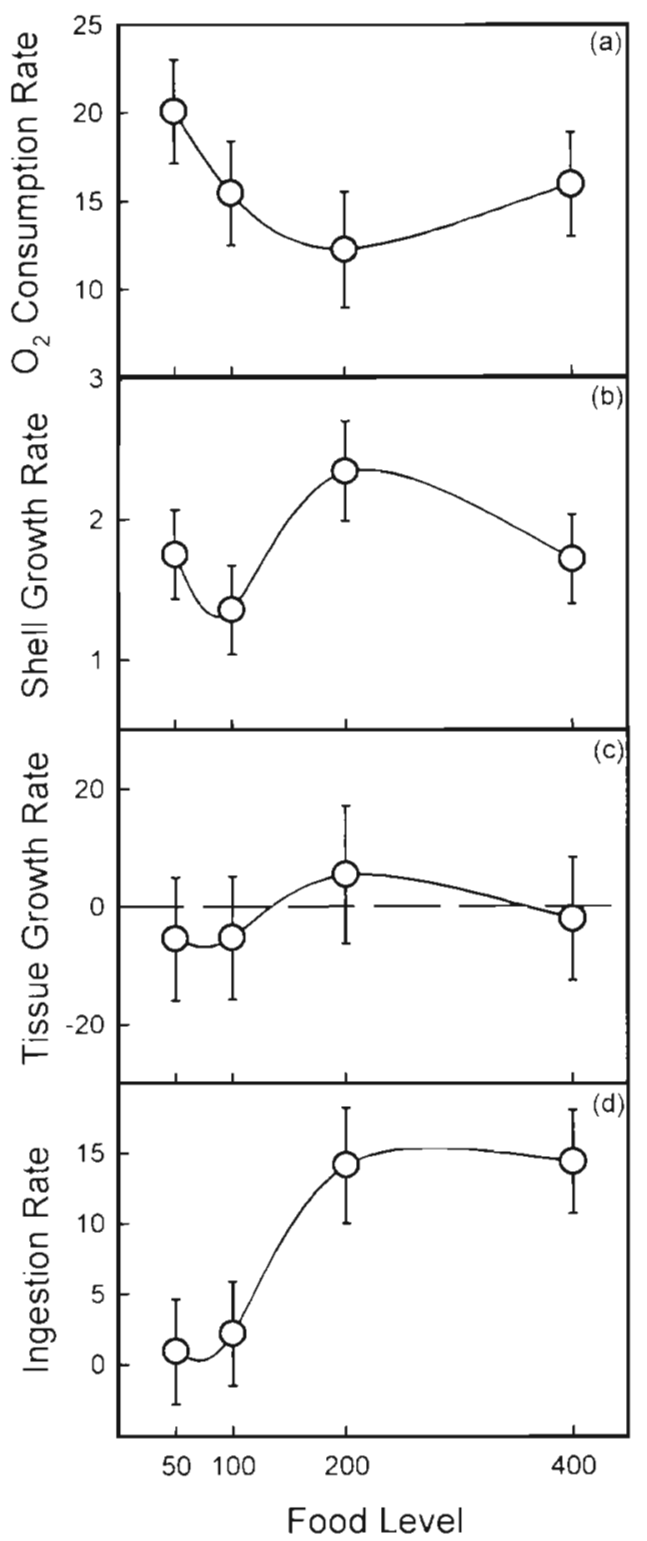

Fig. 2. Mya arenaria. Food experiment results for (a) oxygen consumption rate ( $\mathrm{mg} \mathrm{O} \mathrm{O}_{2}$ per tidal cycle), (b) shell growth ( $\mu \mathrm{m}$. per tidal cycle), (c) soft tissue growth (mg per tidal cycle), and (d) ingestion rate (mg organic carbon per tidal cycle). Food level is expressed as $\mu \mathrm{gg}$ organic carbon $\mathrm{l}^{-1}$. Error bars represent $1 \mathrm{SE}$ 
ably with food level, ranging in some cases by over $100 \%$, but none of these variables showed a significant treatment effect (all $F<1.30$, df $=3,12, p>0.05$; Fig. 2). Shell growth did, however, exhibit a significant block effect $(F=5.39$, df $=4,12, \mathrm{p}<0.05)$.

Shell growth occurred in all treatments, even though food levels were not sufficient to support tissue growth. Mean shell growth rates were significantly greater than zero for all treatments (all $t>4.29$, df $=12$, experimentwise $p<0.01$ ). In contrast, mean tissue weights declined in 3 of the 4 treatments; however, none of the tissue changes were significantly different than zero (all $t<0.52$, df $=12$, experimentwise $p>$ $0.05)$. Soft tissue losses in this experiment indicated that food levels were perhaps too low to support growth, and food concentrations were increased from 2400 to 4800 cells $\mathrm{ml}^{-1}$ in subsequent experiments

There was no trend in shell transparency with treatment, but substantially more individuals had distinct growth increments in the 2 highest food level treatments compared to individuals held at lower food levels (Table 1 ). About $74 \%$ of the individuals examined produced translucent shell material during the experimental period. Almost all of the individuals $(90 \%)$ in the 2 high food level treatments produced distinct growth increments. In contrast, less than half of the individuals in the low food treatments had distinct increments.

\section{Immersion experiment}

Oxygen consumption, shell growth, and tissue growth all exhibited treatment effects, with oxygen consumption and shell growth increasing monotoni- cally with immersion period (Fig. 3). A positive regression trend existed between oxygen consumption and immersion time $(F=55.14$, df $=1,2, p<0.05)$ and between shell growth and immersion time $(F=39.83$, $\mathrm{df}=1,2, \mathrm{p}<0.05)$. Shell growth occurred in all treatments (all $t>7.51, \mathrm{df}=12$, experimentwise $\mathrm{p}<0.01$ ). Tissue growth was affected by treatment $(F=3.95$, df $=$ $3,12, p<0.05)$ but no trend with immersion time was observed $(F=0.11$, df $=1,2, \mathrm{p}>0.05)$. Individuals immersed for $8 \mathrm{~h}$ of the tidal cycle lost weight, but in other treatments, no significant weight changes were measured $(t=3.17$ for $8 \mathrm{~h}$ treatment, other $\mathrm{t}<0.90, \mathrm{df}=$ 12 , experimentwise $p<0.05)$. Ingestion rate did not vary with treatment $(F=1.06, \mathrm{df}=3,12, p>0.05)$, and differences in shell and tissue growth were, therefore, not attributable to differences in energy intake.

Shell growth and oxygen consumption were the only 2 dependent variables to remain coupled during the immersion experiment. A significant positive correlation was found between shell growth and oxygen consumption $(\mathrm{r}=0.998, \mathrm{p}<0.05)$. Correlations between shell growth and soft tissue growth $(r=0.42)$ and between soft tissue growth and oxygen consumption ( $\mathrm{r}=$ 0.37 ) were not significant.

A slight decrease in the number of individuals producing translucent shell material was observed in the high immersion treatments, but there was no trend in the clarity of growth increments with treatment (Table 1). About two-thirds of the individuals in the experiment produced translucent shell material. In the 6 and $8 \mathrm{~h}$ immersion treatments, $83 \%$ of the individuals produced translucent shell. In contrast, $53 \%$ of the clams had translucent shell in the 10 and $11.25 \mathrm{~h}$ immersion period treatments. Over $75 \%$ of the individ-

Table 1. Mya arenaria. Number of shells in each experiment classified by shell transparency and increment clarity. Sample size for each treatment is 9 or 10 shells

\begin{tabular}{|c|c|c|c|c|c|}
\hline \multirow[t]{2}{*}{ Expt } & \multirow[t]{2}{*}{ Treatment } & \multicolumn{2}{|c|}{ Shell transparency } & \multicolumn{2}{|c|}{ Increment clarity } \\
\hline & & Number opaque & Number translucent & Number indistinct & Number distinct \\
\hline \multirow{5}{*}{$\begin{array}{l}\text { Food } \\
\text { expenment }\end{array}$} & Food level $\left(\mu \mathrm{g} \mathrm{C} \mathrm{l}^{-1}\right)$ & & & & \\
\hline & 50 & 3 & 7 & 5 & 5 \\
\hline & 100 & 2 & 8 & 8 & 2 \\
\hline & 200 & 3 & 6 & 1 & 9 \\
\hline & 400 & 2 & 8 & 1 & 9 \\
\hline \multirow{5}{*}{$\begin{array}{l}\text { Immersion } \\
\text { experiment }\end{array}$} & Immersion period (h) & & & & \\
\hline & 6 & 2 & 7 & 1 & 8 \\
\hline & 8 & 1 & 8 & 3 & 6 \\
\hline & 10 & 4 & 6 & 3 & 7 \\
\hline & 11.25 & 5 & 4 & 2 & 7 \\
\hline \multirow{5}{*}{$\begin{array}{l}\text { Temperature } \\
\text { experiment }\end{array}$} & Temperature $\left({ }^{\circ} \mathrm{C}\right)$ & & & & \\
\hline & 5 & 8 & 2 & $3^{a}$ & $7^{\mathrm{d}}$ \\
\hline & 12 & 0 & 10 & 3 & 7 \\
\hline & 20 & 0 & 10 & 4 & 5 \\
\hline & 27 & 0 & 10 & 8 & 2 \\
\hline
\end{tabular}




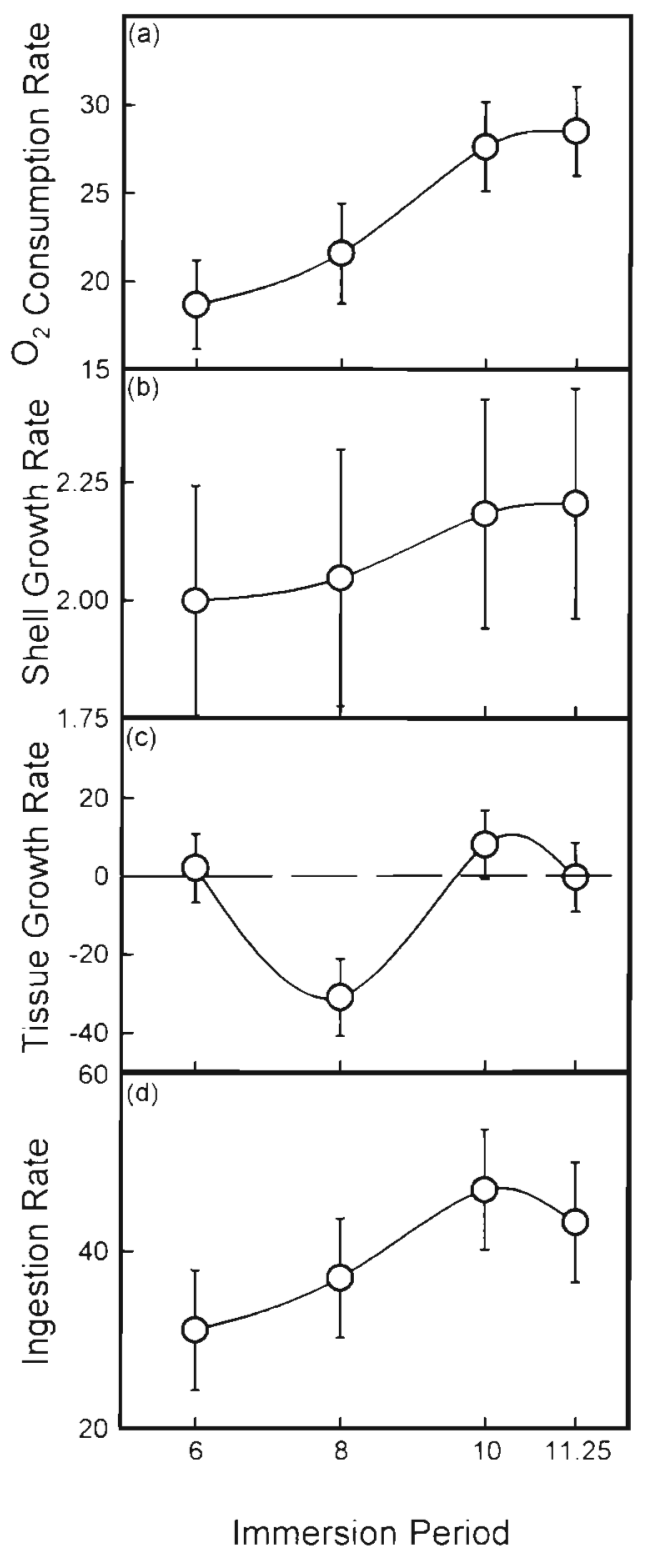

Fig. 3. Mya arenaria. Immersion experiment results for (a) oxygen consumption rate $\left(\mathrm{mg} \mathrm{O}_{2}\right.$ per tidal cycle), (b) shell growth ( $\mu$ m per tidal cycle), (c) soft tissue growth (mg per tidal cycle). and (d) ingestion rate ( $\mathrm{mg}$ organic carbon per tidal cycle). Immersion period is given in hours. Error bars represent $1 \mathrm{SE}$

uals produced distinct growth increments during the experiment, and there was no consistent trend with immersion period.

\section{Temperature experiment}

Oxygen consumption, shell growth, and tissue growth all varied with treatment (Fig. 4). Oxygen consumption increased 2-fold with temperature $(F=14.22$,

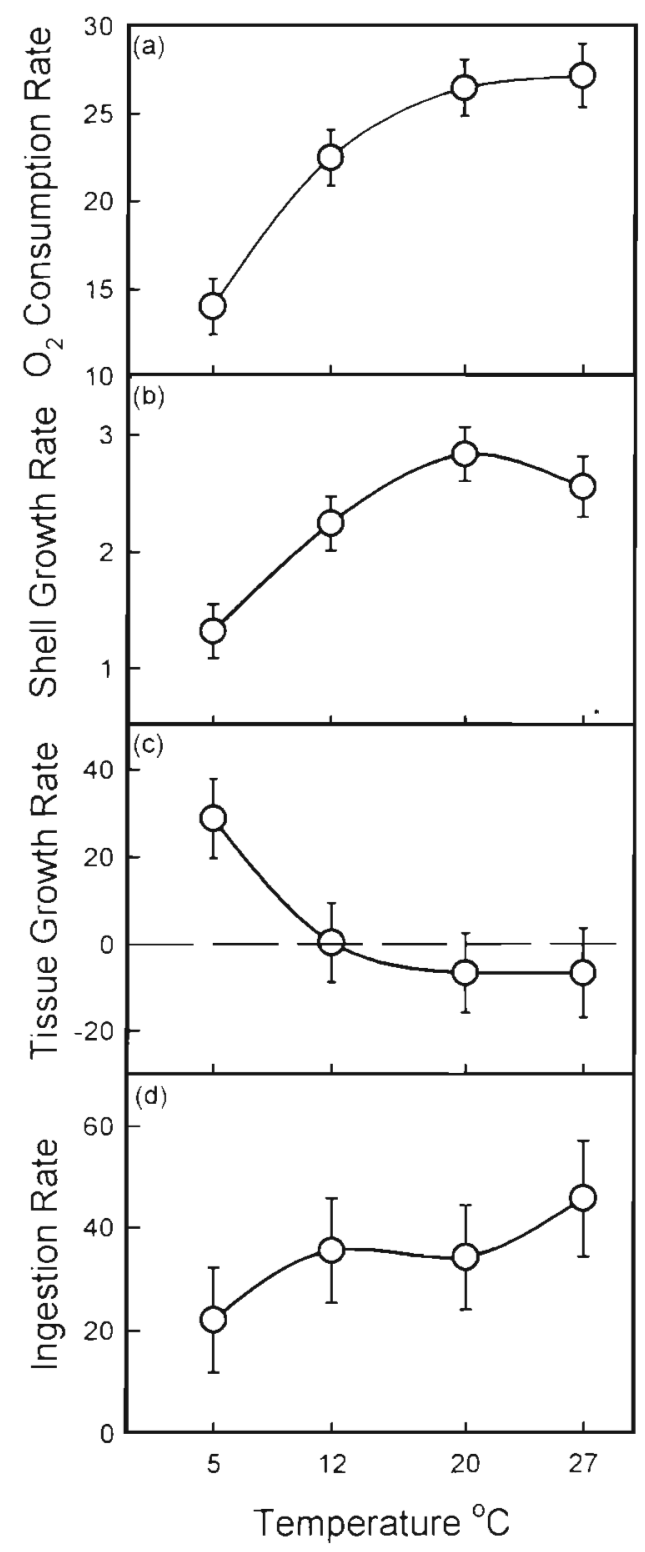

Fig. 4. Mya arenaria. Temperature experiment results for (a) oxygen consumption rate ( $\mathrm{mg} \mathrm{O} \mathrm{O}_{2}$ per tidal cycle), (b) shell growth ( $\mu$ m per tidal cycle), (c) soft tissue growth (mg per tidal cycle), and (d) ingestion rate ( $\mathrm{mg}$ organic carbon per tidal cycle). Error bars represent $1 \mathrm{SE}$

$\mathrm{df}=3,12, \mathrm{p}<0.01)$ and reached an apparent saturation level at $27^{\circ} \mathrm{C}$. Shell growth increased by $114 \%$ from 5 to $20^{\circ} \mathrm{C}$, then declined slightly at the highest experimental temperature $\left(27^{\circ} \mathrm{C}\right)$. Both treatment $(F=7.52$, df $=3,12, \mathrm{p}<0.01)$ and block $(F=5.23, \mathrm{df}=4,12, \mathrm{p}<0.05)$ effects were significant for shell growth. In addition, positive sheli growth occurred in all treatments (all $t>$ $5.69, \mathrm{df}=12$, experimentwise $\mathrm{p}<0.05$ ). In contrast to oxygen consumption and shell growth, tissue growth declined with temperature. Significant treatment $(F=$ 
3.71, $\mathrm{df}=3,12, \mathrm{p}<0.05)$ and block $(F=24.23 \mathrm{df}=4,12$, $p<0.01)$ effects were observed for tissue weight changes. Individuals at $5^{\circ} \mathrm{C}$ gained weight, but no tissue growth was seen at higher temperatures $(t=3.16$ for the $5^{\circ} \mathrm{C}$ treatment, other $t<0.74, \mathrm{df}=12$, experimentwise $p<0.05$ ). Ingestion rate did not vary with temperature $(F=1.14$, df $=3,12, \mathrm{p}>0.05)$, so differences in shell and soft tissue growth were not due to changes in energy intake.

Shell growth was positively correlated with oxygen consumption ( $r=0.975, p<0.05$ ), while tissue growth varied inversely from both shell growth $(r=-0.975, p<$ 0.05 ) and oxygen consumption ( $r=-0.988, p<0.05)$. Correlations between ingestion rate and the other variables were not evaluated since ingestion rate did not significantly vary with temperature.

With increased treatment temperature, shell transparency changed from opaque to translucent, and the frequency of individuals with clearly defined microgrowth increments declined (Table 1). The change from production of opaque to translucent shell material was abrupt between the 5 and $12^{\circ} \mathrm{C}$. Most individuals $(80 \%)$ in the $5^{\circ} \mathrm{C}$ treatment produced opaque shell material during the experimental period. In contrast, all individuals in the 3 higher temperature treatments produced translucent shell. The number of individuals producing distinct growth increments declined gradually from a high of $70 \%$ in the 5 and $12^{\circ} \mathrm{C}$ treatments to a low of $20 \%$ in the $27^{\circ} \mathrm{C}$ treatment. In all $5^{\circ} \mathrm{C}$ individuals with distinct increments, the microgrowth pattern also had the irregular morphology described by Cerrato et al. (1991) as being characteristic of winter growth patterns.

\section{DISCUSSION}

The current research is the first to demonstrate that shell growth remained correlated to a measure of metabolic rate under conditions where shell and tissue growth were uncoupled. Shell and tissue growth were successfully uncoupled in each experiment since positive sheil growth was observed in all treatments, even in those cases where tissue growth was absent or negative. Significant changes in oxygen consumption, shell growth, and tissue growth were observed, however, only in the immersion and temperature experiments. In both these experiments, oxygen consumption, a measure of metabolism, and shell growth were significantly correlated. At the same time, tissue growth was either uncorrelated with oxygen consumption and shell growth, as in the immersion experiment, or negatively correlated with these variables, as in the temperature experiment. These results are consistent, therefore, with the proposal that shell growth is coupled to metabolic rate and is not a direct expression of production.

While many prior studies have observed uncoupling between shell and tissue growth (e.g. Ceccherelli \& Barboni 1983, Bricelj et al. 1984, Frechette \& Bourget 1985, Hilbish 1986, Peterson \& Fegley 1986, Borrero \& Hilbish 1988, Grizzle \& Morin 1989, Hawkins et al. 1989, Harvey \& Vincent 1990), no metabolic measurements were reported; however, a number of other common observations are consistent with a linkage between shell growth and metabolic rate but are inconsistent with or opposite in trend to a relationship between shell growth and production. Unlike tissue growth (i.e. somatic, non-shell production), shell growth during tidal cycle or longer time periods is never negative in bivalves. For example, shell growth is commonly observed in undernourished or starved animals (e.g. Pannella \& MacClintock 1968, Thompson 1975, present study). Pannella \& MacClintock (1968) kept individuals of Mercenaria mercenaria without food for several months. At the end of this time, shells of these animals were sectioned and sets of thin but visible daily microgrowth increments were present. In the present study, shell growth continued in all treatments, even when tissue growth was negative.

Shell growth can also increase dramatically with increased exposure temperature, a phenomenon known as shell shoot that closely resembles the acute effect of temperature change on oxygen consumption. Arnold \& Holland (1976), for example, found that oysters Ostrea edulis $\mathrm{L}$. transferred from a $16^{\circ} \mathrm{C}$ tank to a $24^{\circ} \mathrm{C}$ tank had a greater initial shell growth than oysters remaining in the $16^{\circ} \mathrm{C}$ tank. The elevated temperature would have increased metabolic rate and presumably decreased tissue production in the individuals transferred.

Work elucidating the mechanisms of growth increment formation also clearly supports a critical role for metabolism in shell growth (Lutz \& Rhoads 1977, 1980, Gordon \& Carriker 1978, Rosenberg \& Hughes 1991). Lutz \& Rhoads (1977) proposed that alternating periods of aerobic and anaerobic metabolism were responsible for the formation of microgrowth increments in bivalves. Under immersed conditions, animals metabolize aerobically, and inorganic calcium carbonate is deposited with a protein-rich organic matrix. During periods of exposure, bivalves utilize anaerobic pathways. End products of anaerobic metabolism are organic acids, especially succinic acid, which lower the $\mathrm{pH}$ of the extrapallial fluid. The low $\mathrm{pH}$ dissolves some of the inorganic calcium carbonate, but leaves most of the organic matrix intact. When conditions become oxic again, normal shell deposition resumes. This pattern leaves an increment that is calcium carbonate rich, and a line which is relatively calcium carbonate 
poor and organic rich. Normal semidiurnal tidal cycles would then leave 2 growth increments per day, a pattern seen in many species. Rosenberg \& Hughes (1991) suggested that differences in respiration of the separate mantle tissue sections were responsible for differences in shell form and chemistry. In an analogous theory, a gradient in tissue metabolic activity was proposed by Gauldie \& Nelson (1990) to explain variations in crystalline deposition in otoliths.

In other work, the metabolic enzyme carbonic anhydrase has been intimately linked to shell synthesis (Freeman \& Wilbur 1948, Wheeler 1975, Arnold \& Holland 1976, Kunigelis \& Saleuddin 1983). Carbonic anhydrase catalyzes the conversion of metabolic carbon dioxide to bicarbonate, which then combines with the calcium ion to form calcium carbonate (Wilbur 1964). Inhibition of carbonic anhydrase partially inhibits shell mineralization (Wilbur \& Saleuddin 1983). Wilbur \& Jodrey (1955) measured radiolabeled calcium incorporation into the shell of the oyster Crassostrea virginica in the presence of carbonic anhydrase inhibitors. They found that 2-benzothiazolesulfonamide in concentrations as little as 1:80000 (w/w) reduced shell formation by more than $90 \%$, and concentrations of 1:20000 (w/w) inhibited $98 \%$ of shell formation. The specific activity of carbonic anhydrase has also been shown to increase during shell formation (Arnold \& Holland 1976, Kunigelis \& Saleuddin 1983). In addition, carbonic anhydrase is known to play a role in maintaining the extrapallial fluid $\mathrm{pH}$ (Wheeler 1975), and may also act to buffer organic acids under anaerobic conditions (Wilbur \& Saleuddin 1983).

A distinct change in growth pattern was observed in most shells corresponding to the time the individual was transplanted from the field to the laboratory (Fig. 5). In those individuals collected between fall and spring and producing opaque shell in the field, the transition was especially evident and marked by a change in shell transparency (Fig. 5a). The clarity of growth increments after transplantation ranged from clear to indistinct, and in individuals that began producing indistinct increments in the lab, the transition occurred within a few days of collection. Growth increments during the experiments were generally regularly spaced throughout the 2 to $3 \mathrm{wk}$ period, with the exception of the first 3 to $4 \mathrm{~d}$. This suggests that animals acclimated fairly quickly to experimental conditions. With the exception of individuals with indistinct increments and individuals from the $5^{\circ} \mathrm{C}$ treatment, the number of microgrowth increments produced during the experimental period corresponded closely with the number of tidal cycles and supported the conclusion of Cerrato et al. (1991) regarding the tidal frequency of microgrowth increment formation in Mya arenaria.
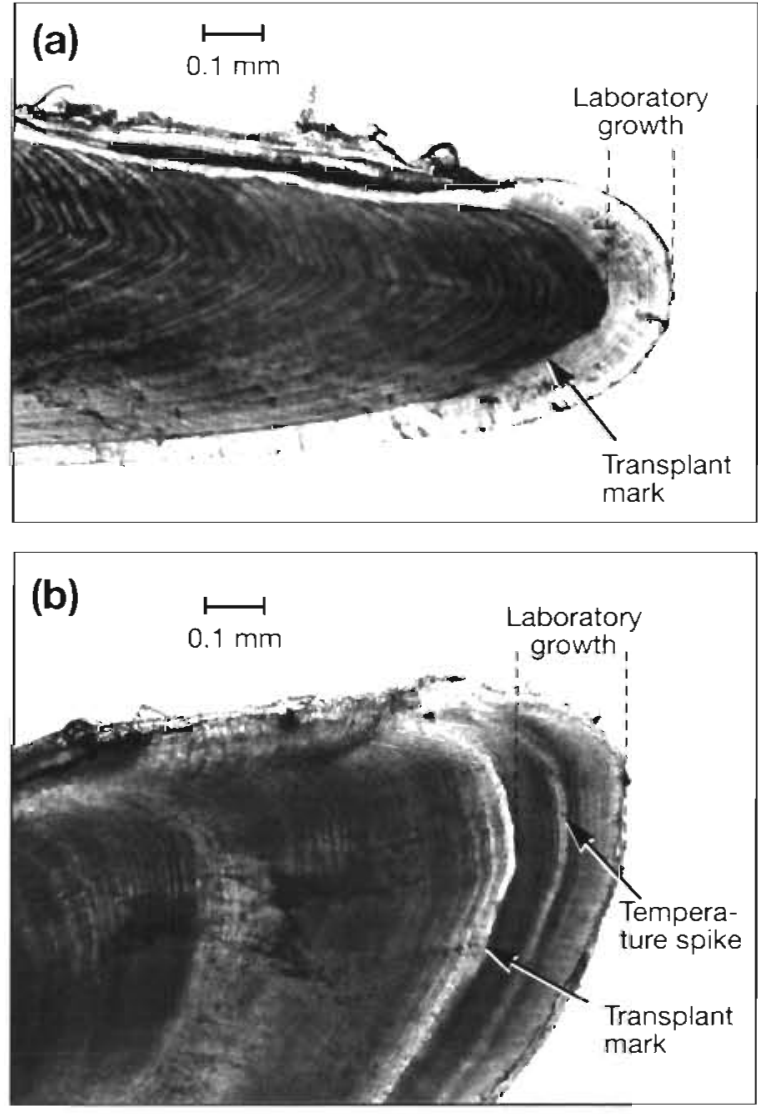

Fig. 5. Mya arenaria. Microgrowth patterns in the chondrophore. Optical micrographs of thin sections illustrating (a) contrast between field and laboratory growth and (b) $24 \mathrm{~h}$ temperature spike

Based on our qualitative assessment, shell transparency appeared to increase with metabolic activity. The number of individuals producing translucent shell material increased between $5^{\circ} \mathrm{C}$, the treatment with the lowest metabolic activity in the temperature experiment, and the 12 to $27^{\circ} \mathrm{C}$ treatments (Table 1). The number of shells classified as translucent tended to decrease with increasing immersion time. This reduction corresponded to a gradual decline in respiration rate (i.e. oxygen consumption/immersion time declined from $3.1 \mathrm{mg} \mathrm{O}_{2} \mathrm{~h}^{-1}$ in the $6 \mathrm{~h}$ treatment to $2.5 \mathrm{mg}$ $\mathrm{O}_{2} \mathrm{~h}^{-1}$ in the $11.25 \mathrm{~h}$ treatment).

Shell transparency changed very quickly in response to an abrupt change in temperature, and this sensitivity was very similar to the acute adjustment in respiration that occurs with short-term temperature changes (e.g see Griffiths \& Griffiths 1987). An example illustrating the effect of a $1 \mathrm{~d}$ elevation in temperature from 15 to $20^{\circ} \mathrm{C}$ is shown in Fig. 5 b. This short-term temperature spike produced a well-defined band of translucent shell. Soft shell clams in the field often form bands of contrasting shell transparency (i.e. a translucent band in the 
middle of an opaque region or an opaque band in a translucent region) that correspond to periods of about 3 to $7 \mathrm{~d}$. Cerrato et al. (1991) termed one such prominent translucent band a 'spawning band', because it was formed in the spring by most individuals in the population at about the same time spawning occurred. As an alternate explanation, we suggest that this band was due to an abrupt increase in water temperature, although this abrupt change could have also induced the animals to spawn. Short-term temperature shock generally leaves a distinct pattern and is a reliable means of marking shells for growth studies (Richardson et al. 1979, Fritz \& Haven 1983, Richardson 1988b, 1989).

Seasonal trends observed in several studies support a relationship between shell transparency and metabolic rate rather than one with production. If shell transparency reflects production, then winter and summer deposition should have similar patterns since production is usually low or negative during both seasons. Cold winter temperatures limit production for many bivalve species in temperate coastal environments, while low food concentrations and high temperature limit production during the summer (Griffiths \& Griffiths 1987). If shell transparency reflects metabolism, shell patterns in these seasons should show the greatest contrast. Cerrato et al. (1991) showed that winter and summer growth patterns were considerably different in Mya arenaria. Winter growth bands were generally opaque, thin and irregular in morphology, while summer bands were translucent, broader and more regular in morphology. Mytilus edulis (Richardson 1989) and Spisula subtruncata (Richardson 1988b) show similar seasonal patterns. In fish, Mosegaard et al. (1988) found that otoliths became more transparent at high temperature.

We suggest that the transparency of the shell and the width of a growth increment are providing somewhat different information about metabolic activity. Transparency of the shell most likely reflects the metabolic rate, while the width of the increment is an integrated measure of metabolic activity over the whole immersion period. Under this proposal, an animal could produce opaque, wide increments if it were metabolizing at a moderate rate over the whole immersion period. Deposition of translucent, thin increments would also be possible if the animal were metabolizing at a high rate but was active during only a small portion of an immersion period. During the rest of the immersion period, activity levels might be reduced and dependent on anaerobic pathways. These 2 types of microgrowth patterns were observed in spring and summer, respectively, by Cerrato et al. (1991).

Increment clarity varied with food concentration and temperature but not with immersion time. The clarity or distinctness of growth increments was generally reduced in the laboratory relative to the period just prior to collection. This is a common occurrence both in the shells of bivalves (Richardson et al. 1979) and in the otoliths of fish (Hovenkamp 1990). The number of individuals producing distinct increments declined at low food levels and at high temperature, suggesting some relationship between increment clarity and stress levels. Individuals in the lowest food level treatments were clearly undernourished, and the $27^{\circ} \mathrm{C}$ treatment was carried out at close to the upper temperature tolerance of Mya arenaria (Malouf \& Bricelj 1989). The irregularly shaped microgrowth increments, observed by Cerrato et al. (1991) to form during the winter in $M$. arenaria, were present in most individuals in the $5^{\circ} \mathrm{C}$ treatment. A similar irregular wrinkled structure was described in otoliths of the Japanese eel held at low temperature (Umezawa \& Tsukamoto 1991).

The failure to observe a trend in increment clarity with immersion time was unexpected. The LutzRhoads hypothesis (Lutz \& Rhoads 1977, 1980) predicts, and research by Richardson (1988a, b, 1989) on a variety of species suggests, that lines separating growth increments should become more distinct as exposure time increases. Richardson (1988a), for example, found that an increased period of exposure from 2 to $4 \mathrm{~h}$ per tidal cycle increased the frequency of 'strong bands' produced in the clam Tapes philippinarum. Two factors may have influenced the results in the present study. First, the frequency of individuals with distinct increments was high in all treatments, so a trend would be difficult to identify (Table 1). Secondly, Richardson et al. (1981) observed in Cerastoderma edule that the strongest lines were produced when a long exposure time was combined with high temperature conditions, such as one would expect to occur during an afternoon low tide. In the present study, air and water temperatures were held at constant levels and animals were maintained in sediments, which further buffered them from temperature fluctuations.

The most serious problem with the experiments in this study was that the dependent variables were measured over widely different time scales, i.e. generally less than $1 \mathrm{~h}$ for feeding and respiration rates, a $12 \mathrm{~h}$ tidal cycle for shell growth, and 2 to $3 \mathrm{wk}$ for tissue growth. We do not feel this problem biased the current results, but our justification for this conclusion and future resolution of the problem merit discussion. For feeding and respiration rates, it was assumed that the measured level of activity was maintained throughout the period of immersion. This assumption is supported by several factors. Most clams began filtering within the first $30 \mathrm{~min}$ of immersion and appeared to remain active for most of the tidal cycle. In preliminary experiments, Mya arenaria showed increased oxygen consumption only during the first 15 min after extending 
its siphon; consumption rates then declined to more moderate, steady levels. Earll (1975a, b) found that the pumping activity cycle of $M$. arenaria is about $5 \mathrm{~min}$ long, i.e. considerably shorter than the measurement period in the present study. However, continuous records of oxygen uptake by Pedersen (1992) indicated variability in both the level and duration of activity in $M$. arenaria. It is important, therefore, that future studies relating shell growth to physiological rates attempt to monitor feeding and oxygen uptake more continuously over the tidal cycle.

A much more difficult problem to resolve is that no short-term (i.e. tidal cycle) tissue growth measure was available. An allometric relationship was used to indirectly estimate the initial tissue weight of individuals. The final weight at the end of a 2 to $3 \mathrm{wk}$ run was measured directly on each individual, but only an average weight change per tidal cycle could be determined with this method. This is a reasonable estimate of tissue growth if, as we believe, acclimation occurred within the first few days of the experiment. Researchers working with fish have been successful at estimating shortterm energy balance by analyzing RNA/DNA ratios (e.g. Buckley 1984, Clemmesen 1988, Hovenkamp 1990). A similar adaptation of this technique may be useful in bivalve studies. Some initial applications of RNA/DNA ratios in bivalves have been carried out by Kenchington (1994) and Paon \& Kenchington (1995).

The results of the present study suggest a number of future research directions to further test the relationship between shell growth and metabolic processes. One promising series of experiments should center around comparing acute to acclimated responses. Some bivalves maintain feeding and metabolic rates at fairly constant levels over a wide environmental range (e.g. acclimatization to seasonal temperature change) but show a distinct acute response to a rapid change in an environmental factor (Bayne \& Newell 1983). Does shell growth acclimate, and does it show an acute response similar to that of metabolic rate? Environmental conditions to be examined should include those within and outside the range of acclimation. Use of carbonic anhydrase inhibitors also has potential for examining the relationship between shell growth and metabolism. While it is known that blocking carbonic anhydrase partially inhibits shell growth (Wilbur \& Saleuddin 1983), it is not known whether this blocking has a similar effect on metabolic rate. In these experiments, it would be very interesting to examine shell transparency changes in addition to the shell growth increment.

Similarities between shell and otolith growth patterns are numerous and some of the common features have been indicated in this manuscript. They include uncoupling between somatic growth and growth of the calcified structure, production of irregular microgrowth patterns at low temperature, increased transparency at high temperature, and reduced increment clarity in field to laboratory transferred individuals. Pannella was the last individual to examine microgrowth patterns in both bivalves and fish (Pannella \& MacClintock 1968, Pannella 1974). We suggest that a comparative study may be rewarding and is long overdue.

Rhoads \& Lutz (1980) have stated that microgrowth patterns are used for 2 distinct purposes: (1) reconstructing the effect of environmental events after they have taken place and (2) obtaining age data critical for estimating growth rate, recruitment, and survivorship. We suggest that microgrowth patterns have the potential to be used in a third way, i.e. to provide information on physiological processes. Our results indicate the potential to estimate respiration rate from field collected individuals by interpreting microgrowth increment patterns in the shell. Current methods (Bayne \& Newell 1983, Griffiths \& Griffiths 1987) involve multiplying laboratory measured values by an arbitrary factor of 2 (Trevallion 1971) to account for higher levels of activity in the field. Use of microgrowth increment patterns would require the oxygen consumption-shell growth relationship to hold over a wide range of environmental conditions. No one laboratory experiment in the present study encompassed the full range field conditions, but the range of conditions experienced by the clams during all the experiments is still substantial. When results from all experiments are combined (Fig. 6), the coefficient of determination between oxygen consumption and shell growth is $\mathrm{r}^{2}=0.74$, if an obvious outlier from the food experiment is removed [regression outlier test (Madansky 1988), $t=3.46$, df $=$ $9, p<0.01]$. Thus, use of microgrowth increment patterns could potentially improve the accuracy of metabolic rate estimates in field populations.

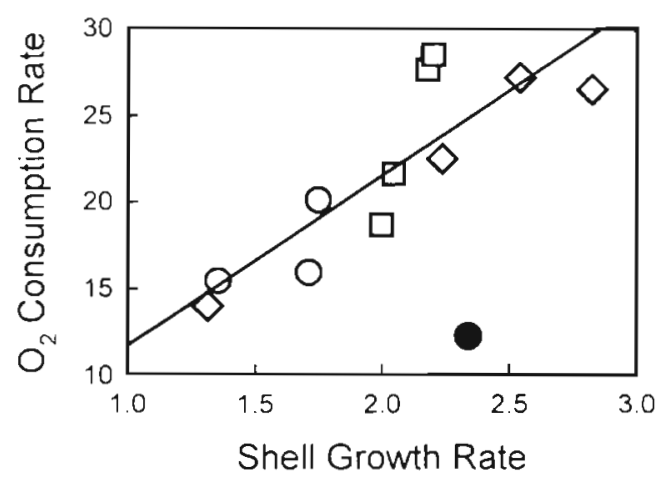

Fig. 6. Mya arenaria. Relationship between oxygen consumption ( $\mathrm{mg} \mathrm{O} \mathrm{O}_{2}$ per tidal cycle) and shell growth ( $\mu \mathrm{m}$ per tidal cycle) for the food $(O)$, immersion $(\square)$, and temperature $(\diamond)$ experiments combined. Coefficient of determination for this relationship is $r^{2}=0.74$ with outlier ( $)$ removed 
Acknowledgements. We thank R. C. Aller for the modified microwinkler technique and help with the respiration chamber design. We also thank V. M. Bricelj and G. R. Lopez for their many comments on this work. This paper is a result of research funded by the National Oceanic and Atmospheric Administration award \# NA46RG0090 to the Research Foundation of State University of New York for New York Sea Grant. The U.S. Government is authorized to produce and distribute reprints for governmental purposes notwithstanding any copyright notation that may appear hereon. The views expressed herein are those of the author(s) and do not necessarily reflect the views of NOAA or any of its sub-agencies.

\section{LITERATURE CITED}

Arnold WM, Holland DL (1976) Carbonic anhydrase activity in the oyster Ostrea edulis L. during rapid shell formation. Biochem Soc Trans 4:477-479

Bayne BL, Newell RC (1983) Physiological energetics of marine molluscs. In: Saleuddin ASM, Wilbur KM (eds) The Mollusca, Vol 4. Academic Press, New York, p 407-515

Borrero FJ, Hilbish TJ (1988) Temporal variation in shell and soft tissue growth of the mussel Geukensia demissa. Mar Ecol Prog Ser 42:9-15

Bricelj VM, Malouf RE, de Quillfeldt C (1984) Growth of juvenile Mercenaria mercenaria and the effect of resuspended bottom sediments. Mar Biol 84:167-173

Buckley LJ (1984) RNA-DNA ratio: an index of larval fish growth in the sea. Mar Biol 80:291-298

Carpenter JH (1965) The Chesapeake Bay Institute technique for the Winkler dissolved oxygen method. Limnol Oceanogr 10:141-143

Ceccherelli VU, Barboni A (1983) Growth survival and yield of Mytilus galloprovincialis L. on fixed suspended culture in a bay of the Po River delta. Aquaculture 34:101-114

Cerrato RM, Wallace HVE, Lightfoot KG (1991) Tidal and seasonal patterns in the chondrophore of the soft-shell clam Mya arenaria. Biol Bull (Woods Hole) 181:307-311

Clemmesen C (1988) A RNA and DNA fluorescence technique to evaluate the nutritional condition of individual marine fish larvae. Meeresforsch 32:134-143

de Zwann A, Wijsman TCM (1976) Anaerobic metabolism in Bivalvia (Mollusca): characteristics of anaerobic metabolism. Comp Biochem Physiol B 54:313-324

Earll R (1975a) Some aspects of heart rate and activity in bivalve molluscs in the laboratory and the natural environment. Doctoral thesis, University of Manchester

Earll R (1975b) Temporal variation in the heart activity of Scrobicularia plana (da Costa) in constant and tidal conditions. J Exp Mar Biol Ecol 15:35-41

Famme P, Knudsen J, Hansen ES (1981) The effect of oxvgen on the aerobic-anaerobic metabolism of the marine bivalve Mytilus edulis L. Mar Biol Lett 2:345-351

Francis MP, Williams MW, Pryce AC, Pollard S, Scott SG (1993) Uncoupling of otoliths and somatic growth in Pagrus auratus (Sparidae). Fish Bull 91:159-164

Frechette M, Bourget E (1985) Food-limited growth of Mytilis edulis $\mathrm{L}$. in relation to the benthic boundary layer. Can $\mathrm{J}$ Fish Aquat Sci 42:1166-1170

Freeman JA, Wilbur KM (1948) Carbonic anhydrase in molluscs. Biol Bull (Woods Hole) 94:55-59

Fritz LW, Haven DS (1983) Hard clam Mercenana mercenaria: shell growth patterns in Chesapeake Bay. Fish Bull 81:697-708

Gauldie RW, Nelson DGA (1990) Otolith growth in fishes. Comp Biochem Physiol A 97(2):119-135
Gordon J, Carriker MR (1978) Growth lines in a blvalve mollusk: subdaily patterns and dissolution of the shell. Science 202.519-521

Griffiths CL, Griffiths RJ (1987) Bivalvia. In: Pandian TJ, Vernberg FJ leds) Animal energetics, Vol 2. Academic Press, New York, p 1-88

Grizzle RE, Morin PJ (1989) Effect of tidal currents seston and bottom sediments on growth of Mercenaria mercenaria: results of a field experiment. Mar Biol 102:85-93

Harvey $M$, Vincent B (1990) Density size distribution energy allocation and seasonal variation in shell and soft tissue growth at two tidal levels of a Macoma balthica (L.) population. J Exp Mar Biol Ecol 142:151-168

Hawkins AJS, Widdows J, Bayne BL (1989) The relevance of whole-body protein metabolism to measured coasts of maintenance and growth in Mytilus edulis. Physiol Zool $62(3): 745-763$

Hilbish TJ (1986) Growth trajectories of shell and soft tissue in bivalves: seasonal variation in Mytilus edulis L. J Exp Mar Biol Ecol 96:103-113

Hoff GR, Fuiman LA (1993) Morphology and composition of red drum otoliths: changes associated with temperature, somatic growth rate, and age. Comp Biochem Physiol 106A:209-219

Hovenkamp F (1990) Growth differences in larval plaice Pleuronectes platessa in the Southern Bight of the North Sea as indicated by otolith increments and RNA/DNA ratios. Mar Ecol Prog Ser 58:205-215

Kenchington ELR (1994) Spatial and temporal variation in adductor muscle RNA/DNA ratio in sea scallops (Placopecten magellanicus) in the Bay of Fundy. Can J Shellfish Res 13:19-24

Kennedy VS, Mihursky JA (1972) Effects of temperature on the respiratory metabolism of three Chesapeake Bay bivalves. Chesapeake Sci 13:1-22

Kunigelis SC, Saleuddin ASM (1983) Shell repair rates and carbonic anhydrase activity during shell repair in Helisoma duryi. Can J Zool 61:597-602

Lewis DE (1996) The relationship between shell microgrowth patterns and physiological energetics of Mya arenaria. MS thesis, Marine Sciences Research Center, State University of New York, Stony Brook

Lowe GA, Trueman ER (1972) The heart and water flow rates of Mya arenaria (Bivalvia: Mollusca) at different metabolic levels. Comp Biochem Physiol 41A:487-494

Lutz RA, Rhoads DC (1977) Anaerobiosis and a theory of growth line formation. Science 198:1222-1227

Lutz RA, Rhoads DC (1980) Growth patterns in the molluscan shell: an overview. In: Rhoads DC, Lutz RA (eds) Skeletal growth of aquatic organisms. Plenum Press, New York, p 203-254

Madansky A (1988) Prescriptions for working statisticians. Springer-Verlag, New York

Malouf RE, Bricelj VM (1989) Comparative biology of clams: environmental tolerances feeding and growth. In: Manzi JJ, Castagna M (eds) Clam mariculture in North America. Elsevier, New York, p 23-73

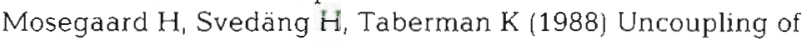
somatic and otolith growth rates in Arctic char (Salvelinus alpinus) as an effect of differences in temperature response. Can J Fish Aquat Sci 45:1514-1524

Nakaoka M, Matsui S (1994) Annual variation in the growth rate of Yoldia notabilis (Bivalvia: Nuculanidae) in Otsuchi Bay northeastern Japan analyzed using shell microgrowth patterns. Mar Biol 119:397-404

Pannella G (1974) Otolith growth patterns: an aid in age determination in temperate and tropical fishes. In: 
Bagenal TB (ed) The ageing of fish. Unwin Brothers, Old Woking, p 28-39

Pannella G, MacClintock C (1968) Biological and environmental rhythms reflected in molluscan shell growth. Paleontol Soc Mem 2:64-79

Paon LA, Kenchington ELR (1995) Changes in somatic and reproductive tissues during artificial conditioning of the sea scallop Placopecten magellanicus (Gmelin 1791). J Shellfish Res 14:51-58

Parsons TR, Maita Y, Lalli CM (1984) A manual of chemical and biological methods for seawater analysis. Pergamon Press, Oxford

Pedersen TF (1992) Temporal variation in heat dissipation and oxygen uptake of the soft-shell clam Mya arenaria L. (Bivalvia). Ophelia 5:203-216

Peterson CH, Fegley SR (1986) Seasonal allocation of resources to growth of shell soma and gonads in Mercenaria mercenaria. Biol Bull (Woods Hole) 171:597-610

Reznick D, Lindbeck E, Byrga H (1989) Slower growth results in larger otoliths: an experimental test with guppies (Poecilia reticulata). Can J Fish Aquat Sci 46:108-112

Rhoads DC, Lutz RA (1980) Skeletal record of environmental change. In: Rhoads DC, Lutz RA (eds) Skeletal growth of aquatic organisms. Plenum Press, New York, p 1-19

Richardson CA (1988a) Exogenous and endogenous rhythms of band formation in the shell of the clam Tapes philippinarum. J Exp Mar Biol Ecol 122:105-126

Richardson CA (1988b) Tidally produced growth bands in the subtidal bivalve Spisula subtruncata. J Mollusc Stud 54 : 71-82

Richardson CA (1989) An analysis of the microgrowth bands in the shell of the common mussel Mytilus edulis. J Mar Biol Assoc UK 69:477-491

Richardson CA, Crisp DJ, Runham NW (1979) Tidally deposited growth bands in the shell of the common cockle Cerastoderma edule (L.). Malacologia 18:277-290

Richardson CA, Crisp DJ, Runham NW (1981) Factors influencing shell deposition during a tidal cycle in the intertidal bivalve Cerastoderma edule. J Mar Biol Assoc UK 61: 465-476

Editorial responsibility: Otto Kinne (Editor), Oldendorf/Luhe, Germany
Rosenberg GD, Hughes WW (1991) A metabolic model for the determination of shell composition in the bivalve mollusc Mytilus edulis. Lethaia 24:84-96

Secor DH, Dean JM (1989) Somatic growth effects on the otolith-fish size relationship in young pond reared striped bass Morone saxatilis. Can J Fish Aquat Sci 46:113-121

Shick JM, de Zwaan A, de Bont AMT (1983) Anoxic metabolic rate in the mussel Mytilus edulis L. estimated by simultaneous direct calorimetry and biochemical analysis. Physiol Zool 56:56-63

Thompson I (1975) Biological clocks and shell growth in bivalves. In: Rosenberg GD, Runcorn SK (eds) Growth rhythms and the history of the earth's rotation. Wiley \& Sons, London, p 149-161

Trevallion A (1971) Studies on Tellina tenuis (da Costa) Ill: aspects of general biology and energy flow. J Exp Mar Biol Ecol 7:95-122

Umezawa A, Tsukamoto K (1991) Factors influencing otolith increment formation in Japanese eel, Anguilla japonica $\mathrm{T}$ and S., elvers. J Fish Biol 39:211-223

Wheeler AP (1975) Oyster mantle carbonic anhydrase: evidence for plasma membrane bound activity and a role in bicarbonate transport. PhD dissertation, Duke University, Durham, NC

Wilbur KM (1964) Shell formation and regeneration. In: Wilbur KM, Younge CM (eds) Physiology of Mollusca. Academic Press, New York, p 243-282

Wilbur KM, Jodrey LH (1955) Studies on shell formation V: the inhibition of shell formation by carbonic anhydrase inhibitors. Biol Bull Mar Biol Lab Woods Hole 108:359-365

Wilbur KM, Saleuddin ASM (1983) Shell formation. In: Saleuddin ASM, Wilbur KM (eds) The Mollusca, Vol 4. Academic Press, New York, p 235-287

Wright PJ, Rowe D, Thorpe JE (1991) Daily growth increments in the otolith of Atlantic salmon parr Salmo salar $\mathrm{L}$. and the influence of environmental factors on their periodicity. J Fish Biol 39:103-113

Wright RT, Coffin RB, Ersing CP, Pearson D (1982) Field and laboratory measurements of bivalve filtration of natural marine bacterioplankton. Limnol Oceanogr 27(1):91-98

Submitted: June 23, 1997; Accepted: August 22, 1997 Proofs received from author(s): October 20, 1997 